\title{
Does fetal MR alter the management of pregnancy in the diagnosis of isolated corpus callosum agenesis?
}

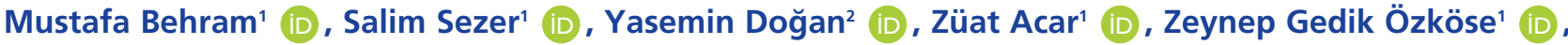 \\ Alper Gezdirici ${ }^{3}$ iD, Ali Gedikbaşı ${ }^{4}$ \\ ${ }^{1}$ Perinatology Unit, Obstetrics and Gynecology Clinic, İstanbul Kanuni Sultan Sïleyman Training and Research Hospital, İstanbul, Turkey \\ ${ }^{2}$ Perinatology Division, Department of Obstetrics and Gynecology, Faculty of Medicine, Kocaeli University, Kocaeli, Turkey \\ ${ }^{3}$ Medical Genetics Department, Istanbul Kanuni Sultan Siileyman Training and Research Hospital, Istanbul, Turkey \\ ${ }^{4}$ Perinatology Unit, Obstetrics and Gynecology Clinic, İstanbul Aydin University, Florya Medical Park, İstanbul, Turkey
}

\begin{abstract}
Objective: To determine if fetal MR alters the management of pregnancy and family decisions in the isolated corpus callosum agenesis (CCA) cases or not.

Methods: Fetal MR was carried out in the cases diagnosed with CCA in the Perinatology Unit of our hospital between 2013 and 2019 after they were differentiated as complex and isolated CCA cases. The impact of MR results on the family decisions and their approaches towards termination were assessed.

Results: A total of 109 out 139 cases were evaluated as isolated CCA. While $93(85.32 \%)$ of them were diagnosed with the complete CCA, $16(14.68 \%)$ cases were diagnosed with the partial CCA. When the period after 2017 during which fetal MR was recommended to all patients was reviewed, it was seen that $7(23.3 \%)$ of 30 cases who underwent fetal MR and 2 (20\%) of 10 cases who did not undergo fetal MR terminated their pregnancies. There was no statistical difference between two groups in terms of the decisions of the patients for gestational termination who did and did not undergo fetal MR.

Conclusion: Fetal MR imaging in the isolated CCA does not change the decisions of the families for the gestational termination. In terms of the termination decision, week of gestation and sociocultural factors may have more impacts.
\end{abstract}

Keywords: Isolated corpus callosum agenesis, complete/partial, fetal MR, gestational termination.

\section{Özet: Fetal MR izole korpus kallozum agenezisi tanısında gebelik yönetimini değiştirir mi?}

Amaç: İzole korpus kallozum agenezisi (CCA) olgularında fetal MR'nin gebelik yönetimi ve aile kararlarını değiştirip değiştirmediğini saptamak.

Yöntem: Çalışmaya katılan, 2013-2019 yılları arasında hastanemiz Perinatoloji Ünitesinde CCA tanısı alan olgulara, kompleks ve izole CCA şeklinde ayırt edildikten sonra fetal MR uygulandı. MR sonuçlarının aile kararları üzerine etkisi ve terminasyon düşüncesine yaklaşımları incelendi.

Bulgular: Toplam 139 olgunun 109 tanesi izole CCA olarak değerlendirildi. Bu olguların 93 tanesine (\%85.32) komplet CCA tanısı konulurken, 16 olgu (\% 14.68) parsiyel CCA tanısı aldı. Tüm hastalara fetal MR önerilen 2017 sonrası dönem incelendiğinde, fetal MR çekimi yaptıran 30 olgunun 7 tanesi (\%23.3) ile yaptırmayan 10 olgunun 2 tanesinin (\%20) gebelik sonlandırması yoluna gittiği görüldü. Fetal MR çektiren ve çektirmeyen hastaların gebelik sonlandırması kararları açısından iki grup arasında istatistiksel bir fark görülmedi.

Sonuç: İzole CCA'da fetal MR görüntülemesi ailelerin gebeliğin sonlandırılmasına ilişkin kararını değiştirmemektedir. Gebelik sonlandırması açısından gebelik haftası ve sosyo-kültürel etkenlerin etkisi daha fazla olabilir.

Anahtar sözcükler: İzole korpus kallozum agenezisi, komplet/parsiyel, fetal MR, gebelik sonlandırması.

\section{Introduction}

Corpus callosum (CC), originating from white matter, is the greatest interhemispheric connection between the hemispheres. ${ }^{[1,2]}$ These connections play a significant role in the integration of sensational, motor and cognitive functions. ${ }^{[2]}$ Complete agenesis, partial agenesis, hypopla- sia and hyperplasia are among the developmental anomalies of CC during fetal process, and the prevalence of $\mathrm{CC}$ anomalies vary according to the population, which is $1.8 / 1000$ birth in the general population and increases up to $3 \%$ in the societies displaying developmental disabilities. ${ }^{[3,4]}$ The callosal anomalies (CA), including other cere-

Correspondence: Ali Gedikbaşı, MD. Perinatology Unit, Obstetrics and Gynecology Clinic, İstanbul Kanuni Sultan Süleyman Training and Research Hospital, İstanbul, Turkey. e-mail: alged_1971@yahoo.com / Received: April 29, 2020; Accepted: June 23, 2020

Please cite this article as: Behram M, Sezer S, Doğan Y, Acar Z, Gedik Özköse Z, Gezdirici A, Gedikbaşı A. Does fetal MR alter the management of pregnancy in the diagnosis of isolated corpus callosum agenesis? Perinatal Journal 2020;28(2):113-119. doi:10.2399/prn.20.0282015 
bral and extra-cerebral malformations, are associated with the chromosomal pathologies and genetic syndromes. Therefore, the general prognosis of CA is controversial, and neurodevelopmental delay is seen frequently in the presence of additional anomaly. ${ }^{[5]}$ The etiology of corpus callosum agenesis (CCA) is heterogeneous in this regard; it may exist as a component of Aicardi syndrome, and it may coexist with CNS malformations such as Dandy-Walker or Arnold-Chiari malformation. Besides, CCA may also be associated with holoprosencephaly, schizencephaly, TORCH or Zika virus infections. Genetic interaction may occur depending on autosomal dominant, autosomal recessive or $\mathrm{X}^{[6]}$ While $30-35 \%$ of the genetic reasons can be identified depending on the syndromes, $20-35 \%$ of them are under the influence of monogene. Major chromosomal anomalies such as trisomy 18 , trisomy 13 or mosaic trisomy 8 were found in $18 \%$ of CCA cases. ${ }^{[7]}$

Fetal ultrasonography and neurosonography are the basic / primary imaging methods, and they can be used after 18 weeks of gestation. Normal CC development may also be imaged indirectly by revealing pericallosal artery before 18 weeks of gestation, but this practice is not recommended in the routine evaluation for the final diagnosis. ${ }^{[8]}$ It has been found out in the recent years that fetal MR imaging can be used to confirm the diagnosis and it may provide information about the related fetal central nervous system anomalies including cortical development disorders in particular, and that it can change the prognosis and clinical management with the help of additional fetal clinical findings in $20 \%$ of the cases after 24 weeks of gestation. ${ }^{\left[{ }^{[]}\right.}$

The aim of our study is to evaluate the impact of additional fetal MR practice on the decisions of families for gestational termination (GT) in the patients diagnosed with isolated CCA.

\section{Methods}

The fetuses diagnosed with CCA in the Perinatology Unit of İstanbul Kanuni Sultan Süleyman Training and Research Hospital between 2013 and 2019 were included in this retrospective study. All fetuses with CCA pre-diagnosis/diagnosis were evaluated by detailed sonographic and neurosonographic (GE Healthcare Ultrasound E6; RAB 6D [2-7 MHz] probe; Milwaukee, WI, USA) examinations in terms of additional anomalies. The patients were assessed in two groups as the fetuses with isolated and non-isolated/complicated CCA diagnosis.
The fetal neurosonography for the pregnant women was conducted transabdominally on axial, sagittal and coronal planes in accordance with the guidelines published by ISUOG (International Society of Ultrasound in Obstetrics and Gynecology) in 2007. ${ }^{[10]}$ The anatomic parts (rostrum, genu, truncus and splenium) of $\mathrm{CC}$ were evaluated in all fetuses and the total lengths and thicknesses of CCs were measured. In addition, all cases underwent detailed anomaly examination and fetal echocardiography screening. The transvaginal fetal examination was carried out in the cases which were not on cephalic position in accordance with the recommendations of Timor-Trisch and Monteagudo. ${ }^{[11]}$ The diagnosed cases were recommended karyotype analysis after they were provided genetic consultation. Fetal MR imaging was done by using $1.5 \%$ system (General Electric Healthcare, Explorer 1.5T; Milwaukee, WI, USA) without sedation. Ultra T2 weighted single-shot fast spin echo imaging was used for axial, coronal and sagittal planes with 2-3 mm section thickness, and it was for the detection of early myelination. In addition, T1 radiofrequency sections were taken on axial planes, and these sections were applied for fat tissue to reveal myelin structure in the developed brain and bleeding.

It was started to conduct fetal MR as a routine practice for the patients with isolated CCA diagnosis after 2017 in our institution. While fetal MR imaging was a partial practice before 2017 in accordance with the recommendations of the international guidelines, all cases admitted to our hospital as of this date were recommended and imaging was conducted in the cases whose families accepted. In our study, the sonography results of the patients diagnosed with isolated partial CCA (pCCA) and isolated complete CCA (cCCA) were checked with fetal MR and their diagnosis compatibilities were evaluated. After the families together with the diagnosed fetuses were re-examined in the multidisciplinary perinatology council of our family, they were informed about the postpartum outcomes, risks and prognosis of isolated pCCA and cCCA cases through the consultation of pediatric neurology unit, and the gestational termination was offered to the families as an option.

The variables evaluated in the study were the demographic data of the pregnant women, diagnosis age during pregnancy, week of gestation during fetal MR, additional cranial and extracranial malformations, karyotype results and the impacts of related results on the decision of families for the gestational termination. 

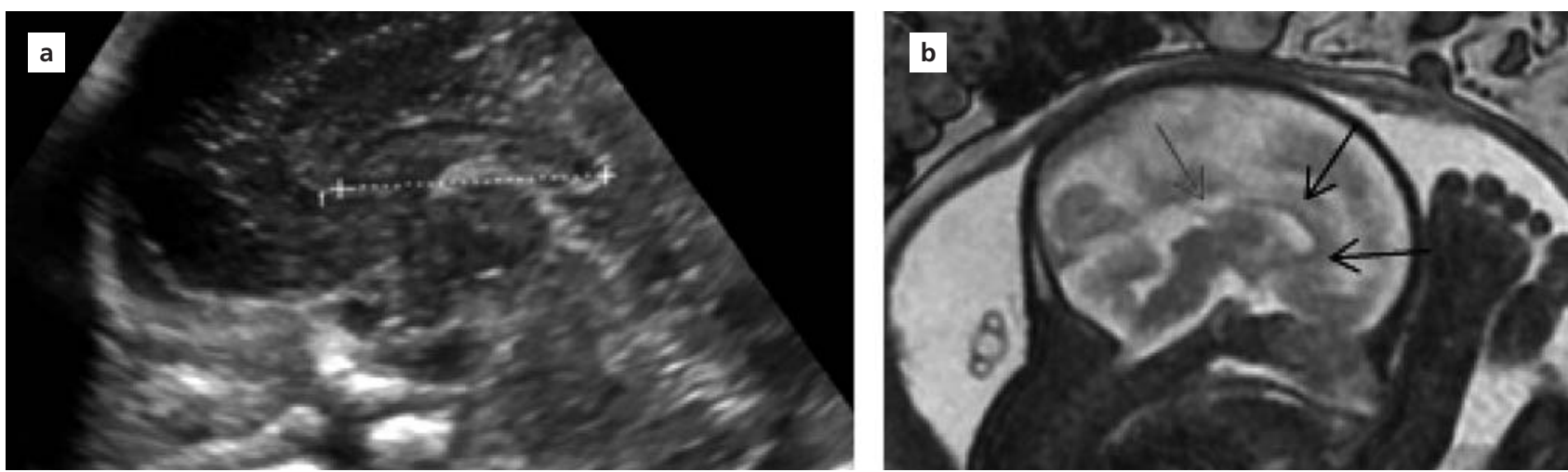

Fig. 1. Isolated partial CCA case. (a) Isolated partial CCA diagnosis after corpus callosum (CC) measured shorter according to the week of gestation in the fetus at 24 weeks of gestation. (b) It is seen that the splenium part is missing in CC structure after the fetal MR was performed in the same patient.

SPSS 23.0 (Statistical Packages for Social Sciences; SPSS Inc., Chicago, IL, USA) was used for the statistical analyses. The numerical data were presented as mean \pm standard deviation and range (min-max), and the categorical data were represented as percentage (\%) in the evaluation. TOP values of the cases who did and did not undergo MR were compared by using Kruskal-Wallis test (in $95 \% \mathrm{CI}, \mathrm{p}<0.05$ is significant).

\section{Results}

Of 139 cases diagnosed with CCA in our hospital or admitted to our hospital through referral, 109 (78.4\%) were evaluated as isolated CCA. Additional anomaly/ anomalies were found in other $30(21.6 \%)$, and they were evaluated as non-isolated/complicated cases (Fig. 1). The mean age of the pregnant women with isolated CCA diagnosis was $28.6 \pm 6.4$, and their mean week of gestation during diagnosis was $28.6 \pm 4.8$. The demographic characteristics of both groups are shown in Table $\mathbf{1}$. The mean age of the patients in the isolated CCA group was 28.63 \pm 6.43 , and the mean week of gestation was $22.67 \pm 3.50$ months in the non-isolated/complicated CCA group. This difference was significant in terms of age variable in the both groups $(\mathrm{p}=0.041)$. When mean gravida was compared between two groups, it was seen that the mean gravida of the patients in the isolated CCA group $(2.42 \pm 1.43)$ was higher than the mean value of the patients in the non-isolated/complicated CCA group $(1.13 \pm 2.59)$, but this difference was not significant. Similarly, the mean parity of the patients in the isolated CCA group $(1.04 \pm 1.09)$ was slightly higher than the values of non-isolated/complicated CCA group $(0.52 \pm 1.29)$, but it was not significant. The ultrasonographic diagnosis was established at $28.66 \pm 4.86$ weeks in in the isolated CCA cases while the diagnosis was established at $26.57 \pm 3.45$ weeks in the other group. The week of gestation during diagnosis was statistically significant for both groups $(\mathrm{p}=0.028)$.

When all patients are considered, 93 (85.3\%) of isolated CCA cases were evaluated as cCCA and $16(14.7 \%)$ of them were evaluated as pCCA after the detailed assessment conducted in our clinic. Twenty-seven cases diagnosed with cCCA and 7 cases diagnosed with pCCA underwent fetal MR imaging. After fetal MR imaging, it was observed that MR diagnoses were fully compatible with cCCA diagnosis of the fetuses (US/MR diagnosis compatibility for cCCA diagnosis: $27 / 27$ cases) and highly compatible with pCCA diagnosis of the fetuses (US/MR diagnosis compatibility for pCCA diagnosis: 5/7 cases) (Fig. 2). Accordingly, neurosonography and fetal MR were compatible for $94 \%$ of the cases. Of the two patients who were observed to have incompatible US/fetal MR results, inferior vermian hypoplasia was found in the first one as an additional anomaly. For the

Table 1. The demographic characteristics of the cases.

\begin{tabular}{lccc} 
& $\begin{array}{c}\text { Isolated CCA } \\
(\mathbf{n = 1 0 9 ; 7 8 . 4 \% )} \\
\text { mean } \pm \mathbf{s t d}\end{array}$ & $\begin{array}{c}\text { Non-isolated / } \\
\text { complicated CCA } \\
(\mathbf{n}=\mathbf{3 0} ; \mathbf{2 1 . 6 \% )} \\
\text { mean } \pm \text { std }\end{array}$ & p-value \\
\hline Age & $28.63 \pm 6.43$ & $22.67 \pm 3.50$ & $0.041^{*}$ \\
Gravida & $2.42 \pm 1.43$ & $1.13 \pm 2.59$ & 0.234 \\
Parity & $1.04 \pm 1.09$ & $0.52 \pm 1.29$ & 0.325 \\
$\begin{array}{l}\text { Week of gestation } \\
\text { during diagnosis }\end{array}$ & $28.66 \pm 4.86$ & $26.57 \pm 3.45$ & $0.028^{*}$ \\
\hline
\end{tabular}

${ }^{*} p<0.05$. 
second patient, a fetus diagnosed with cCCA by sonography during antenatal period was reported to have CC hypoplasia after fetal MR. It was seen that the last diagnosis of postnatal MR was also cCCA in this patient who was followed up during pregnancy.

Similarly, when the period after 2017 in which all patients were recommended fetal MR was reviewed, it was seen that 24 of 34 pregnant women who were established the preliminary diagnosis of cCCA accepted further investigation and underwent fetal MR, and US/MR compatibility was observed. Five of 6 patients who were recommended fetal MR due to the preliminary diagnosis of partial CCA accepted further investigation and US/MR compatibility was observed in these patients as well (Fig. 3).

The decisions of the families for the gestational termination, who did / did not undergo fetal MR during antenatal period, were assessed in the council and provided consultation by the pediatric neurology, were evaluated. When all patients were assessed, it was seen that gestational termination was preferred for $8(23.5 \%)$ fetuses in the group $(n=34)$ that underwent fetal MR imaging, and 16 families in the group $(\mathrm{n}=75)$ which did not undergo MR imaging. When diagnosis distribution was conducted for these 24 cases, it was seen that 20 (21.5\%) of isolated CCA cases were cCCA and 4 (25\%) of them were pCCA cases. There was no statistically significant difference between 34 cases who underwent fetal MR imaging and 75 cases who did not undergo fetal MR imaging ( $\mathrm{p}=0.624)$. While $8(23.5 \%)$ of the families accepted gestational termination according to the fetal MR result in isolated CCA anomaly cases, 16 (21.3\%) of them did not accept it. There was no difference for the decisions of gestational diagnosis in terms of isolated CCA diagnosis $(\mathrm{p}=0.078)$.

When the period after 2017 during which all patients were recommended fetal MR was reviewed, it was seen that $7(23.3 \%)$ of 30 cases who underwent fetal MR imaging and 2 (20\%) of 10 cases who did not undergo fetal MR imaging preferred the gestational termination. During this period, 7 (23.3\%) families in the isolated CCA anomaly cases accepted gestational termination according to the fetal MR results while $20 \%$ of the patients who did not undergo fetal MR imaging did not accept termination $(\mathrm{p}=0.212)$.

In our study, we used Kruskal-Wallis test to investigate the impact of fetal MR result on the termination decisions of families in isolated CCA anomaly cases statistically; no statistically significant difference was found

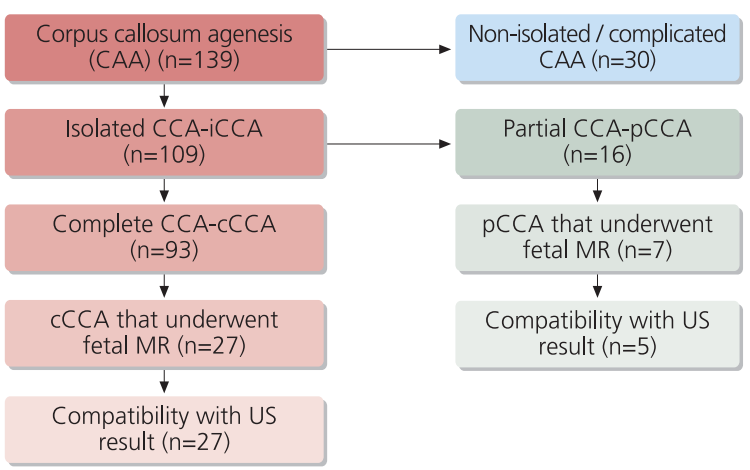

Fig. 2. Flowchart of the cases with corpus callosum agenesis (CCA) (all cases). cCCA: complete corpus callosum agenesis; iCCA: isolated corpus callosum agenesis; pCCA: partial corpus callosum agenesis; US: ultrasonography.

between all patients during both periods and between the groups during the period after 2017 ( $\mathrm{p}=0.098 ; 95 \%$ CI, p<0.05) (Table 2).

42 pregnant women diagnosed with cCCA and 7 pregnant women diagnosed with pCCA underwent invasive procedure for karyotype analysis in terms of genetic diagnosis during diagnosis and follow-up processes. The diagnosis was trisomy 21 only in one fetus diagnosed with cCCA, and it was seen that this fetus died at the 34 weeks of gestation during gestational follow-up.

In addition, intrauterine loss was observed for 3 other fetuses diagnosed with pCCA during antenatal follow-up after diagnosis. Only one of them underwent fetal MR imaging, and none of the cases accepted karyotype offer after diagnosis.

\section{Discussion}

The screening at axial and sagittal planes for the image sections of fetal anterior and mid-brain is done by imag-

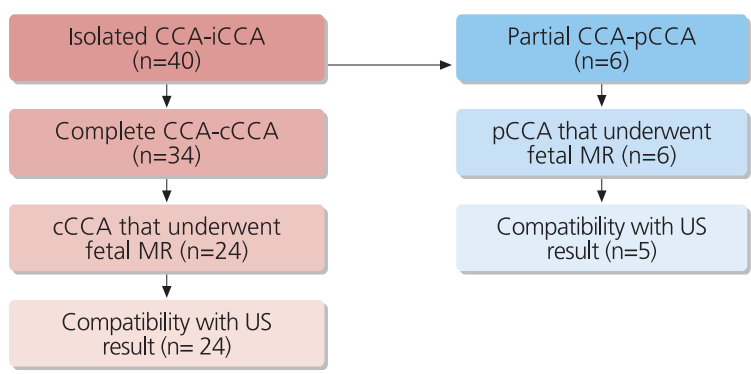

Fig. 3. The flowchart of the cases with isolated corpus callosum agenesis (CCA) after 2017. cCCA: complete corpus callosum agenesis; iCCA: isolated corpus callosum agenesis; pCCA: partial corpus callosum agenesis; US: ultrasonography. 
ing cavum septum pellucidum (CSP) and ventricles in the head. ${ }^{[10,1]}$ While cCCA diagnosis is established by the failure of imaging corpus callosum through direct imaging in the sagittal sections, incompatibilities related with the length or thickness of CC or malformations are considered among the findings of pCCA and CC hypoplasia. ${ }^{[12]}$ On the other hand, the failure of imaging CSP in the standard cranial axial sections, CS width, length or the disproportions between them, interhemispheric fissure mark (three-line view consisting of the medial margins of falx and hemispheres), atrial width being ? $10 \mathrm{~mm}$ and the presence of medium severity of ventriculomegaly, the colpocephaly view formed by the dilation of occipital horns related with the non-development of the posterior part of $\mathrm{CC}$, the tear drop view of the lateral ventricles, and more separate view of lateral ventricles from each other are among the indirect findings in the sonography. The displacement of 3rd ventricle upwards in the coronal sections and delta-like view are considered among the indirect findings. Lastly, the pathological course of pericallosal arteries is also among the findings of CCA. While these sonographic findings can be seen in cCCA distinctly, they can be seen partially or nonspecifically in the cases diagnosed with pCCA. In this regard, CSP helps us more: although CSP development has a pathological view usually in cCCA cases, the posterior part of CC generally has a developmental disorder (not a rule) and CSP view is preserved in pCCA cases. ${ }^{[12-18]}$

In the literature, the incidence of chromosomal anomaly was reported as high as $17.8 \%$ in the cases diagnosed with CCA ${ }^{[16]}$ However, this rate is not only for isolated cases but applies for all patients diagnosed with CCA whereas our case included only the cases diagnosed with isolated CCA. We found Trisomy 21 (the incidence of aneuploidy was $2.2 \%$ ) only in one of 49 fetuses after karyotype analysis in our series. As we excluded multiple anomalies from our study, we did not observe potentially higher aneuploidy rates in our study. However, as poor postnatal development possibility usually can be seen highly together with euploidy series in CCA cases even the isolated ones, microarray first and then exome sequencing, if necessary, as a two-step process in the prenatal genetic panel are the additional recommendations that can be done for the diagnostic test during antenatal process. ${ }^{[19]}$ Sub-microscopic copy number variation (CNV) can be seen with a rate of 3.1-7.9\% in the fetuses which are found to have limited anomaly by a single system in the sonography but found to be euploidy in the classic karyotyping, and it provides more detailed information about fetal prognosis together with phenotype. ${ }^{[2]}$
Table 2. The impact of fetal MR results on the termination decision of families in isolated CCA anomaly cases (total and routine imaging procedures after 2017).

\begin{tabular}{lccc} 
& $\begin{array}{c}\text { Cases who } \\
\text { underwent } \\
(\mathbf{n}, \%)\end{array}$ & $\begin{array}{c}\text { Cases who did } \\
\text { not undergo } \\
\mathbf{( n , \% )}\end{array}$ & p-value \\
\hline $\begin{array}{l}\text { Total } \\
\text { Fetal MR imaging }\end{array}$ & 34 & 75 & 0.624 \\
Gestational termination & $8(23.5 \%)$ & $16(21.3 \%)$ & 0.078 \\
\hline After 2017 & 30 & 10 & 0.315 \\
Fetal MR imaging & $7(23.3 \%)$ & $2(20.0 \%)$ & 0.212 \\
\hline Gestational termination & & & \\
\hline
\end{tabular}

Kruskal-Wallis test. ${ }^{*} \mathrm{p}<0.05$

Paladini et al. evaluated different sonographic cranial findings in their study ${ }^{[12]}$ and they found ventriculomegaly in about $26 \%$ of the fetuses diagnosed before the 24 weeks of gestation and in $74 \%$ of the fetuses diagnosed after the 24 weeks of gestation. Similarly, they found colpocephaly finding in about $21 \%$ of the cases diagnosed before the 24 weeks of gestation and in $69 \%$ of the cases diagnosed after the 24 weeks of gestation. It is seen that the ventricles dilate by becoming clearer after the 24 weeks of gestation in fetuses diagnosed with both pCCA and cCCA. In another study assessing ventriculomegaly, 10 (13.5\%) of 74 fetuses with lateral ventricle more than $10 \mathrm{~mm}$ were diagnosed with $\mathrm{CCA}^{[16]}$ This correlation shows both the importance and the difficulty of imaging CC in fetuses with ventriculomegaly. Similarly, Paladini et al.$^{[12]}$ showed that the colpocephaly finding which is an indirect indicator of CCA becomes clear as the weeks of gestation advance. Conversely, the failure of imaging CSP in the same study was assessed only for pCCA cases, and the failure of imaging CSP was observed in $35.3 \%$ of the cases younger than 24 weeks while the rate was $20 \%$ in cases above 24 weeks. Karl et al. reported that pCCA diagnosis can be established more easily through the differences between CSP shapes and rates. ${ }^{[17]}$ Similarly, Shen et al. also presented the data showing that CSP deformities could be an indirect indicator for pCCA diagnosis. ${ }^{[21]}$

Although there is a general literature information stating that the fetal MR imaging for distinctive diagnosis after the preliminary diagnosis of ventriculomegaly may detect additional $15-20 \%$ pathologies, it is usually not specified whether the sonography procedure is carried out by experienced experts or not when comparing both methods. ${ }^{[6,11-14]}$ However, fetal MR was highlighted more for the investigation of a general multi-etiological finding such as ventriculomegaly through partial bias in the early 2000 s. $^{[22]}$ The arguments such as the exact number of intracranial pathologies which do not require MR and established the final diagnosis with the sonography and 
the direct MR request instead of neurosonography and transvaginal sonography procedures, if necessary, after the preliminary diagnosis by transabdominal sonography were suggested among the primary topics as the reasons of bias. ${ }^{[23]}$ This argument started discussions among those working on radiology, fetal sonography and imaging fields in terms of developing algorithms. ${ }^{[9,23]}$ However, many studies reported that the diagnosis during prenatal period can be provided via sonography/neurosonography by the experts without fetal MR or independent from fetal MR in both isolated $\mathrm{cCCA}^{[12,13,24,25]}$ and isolated pCCA $^{[12,13,26,27]}$ cases. Accordingly, Malinger et al. suggested in their editorial article for the evaluation of CCA diagnosis that the limitation of cranial evaluation only with the axial sections and the exclusion of sagittal and coronal sections from the examination are the most important issues missing in the sonographic examination. ${ }^{[28]}$

After the ventriculomegaly diagnosis published most recently on this topic, the rate of detecting additional anomaly after neurosonography was $5.0 \%$ while it was $16.8 \%$ after only standard axial sections for the anomalies in which the neurosonography was applied/not applied before fetal MR. The rate of detecting additional anomaly in the birth after prenatal MR was reported $0.9 \%$. It was reported that maternal body mass index (BMI), the cases with medium-severe level ventriculomegaly more than mild ventriculomegaly and fetal MR conducted after 24 weeks of gestation were among the factors affecting the detection of additional anomaly. ${ }^{[2,30]}$ Although the fetal MR conducted before 24 weeks of gestation also performs well, the cortical and white matter anomalies and intracranial hemorrhage diagnoses were the diagnosis groups which made fetal MR superior at the third trimester. ${ }^{[28,29]}$

According to the literature data, prognosis cannot be predicted in pCCA cases due to the uncertainty of antenatal, postnatal and newborn processes. ${ }^{[18]}$ In our clinic, we routinely recommend diagnosed families the gestational termination due to these unpredictable prognosis conditions. In this way, four pCCA cases decided to terminate pregnancy while three of them which rejected termination had intrauterine fetal loss after 32 weeks of gestation. Therefore, the families diagnosed with pCCA should also be informed the fact that they may encounter the risk of spontaneous intrauterine fetal death during pregnancy follow-up.

There is a limited number of publications on the contribution of fetal MR to the gestational termination. In the review of Di Mascio et al., ${ }^{[30]}$ the rate of gestational termination request after standard sonography was $5.1 \%$ while it was $2.9 \%$ after the fetal MR which was added later. Similar to our study, it can be concluded that we need to investigate other factors rather than the diagnosis type in terms of convincing patients. A study investigating gestational termination in our society reported that newborn being incompatible with life after pregnancy, multiple anomalies and pathologies such as chromosomal / genetic anomalies are more prominent reasons than mental retardation. ${ }^{[14]}$ Similarly, another study reported that the early diagnosis of anomaly was one of the leading reasons for preferring termination in the conservative societies. ${ }^{[3]}$

\section{Conclusion}

In relation to our study, we found similar diagnostic accuracies in the fetal MR and regular multi-sectional prenatal sonographic examinations for the prenatal diagnosis of CCA. On the other hand, we concluded that conducting fetal MR imaging for the decision of gestational termination and/or the confirmation of diagnosis does not change the decision of parents for the gestational termination. Further studies are required on the gestational termination, and the impacts of multifactorial topics such as socio-cultural and religious perspective of families/mothers, week of gestation during diagnosis and additional methods should be investigated.

Conflicts of Interest: No conflicts declared.

\section{References}

1. Alby C, Malan V, Boutaud L, Marangoni MA, Bessieres B, Bonniere $\mathrm{M}$, et al. Clinical, genetic and neuropathological findings in a series of 138 fetuses with a corpus callosum malformation. Birth Defects Res A Clin Mol Teratol 2016;106:36-46. [PubMed] [CrossRef]

2. Paul LK, Brown WS, Adolphs R, Tyzka JM, Richards LJ, Mukherjee P, et al. Agenesis of the corpus callosum: genetic, developmental and functional aspects of connectivity. Nat Rev Neurosci 2007;8:287-99. [PubMed] [CrossRef]

3. Glass HC, Shaw GM, Ma C, Sherr EH. Agenesis of the corpus callosum in California 1983-2003: a population-based study. Am J Med Genet A 2008;146A:2495-500. [PubMed] [CrossRef]

4. Jeret JS, Serur D, Wisniewski KE, Fisch C. Frequency of agenesis of the corpus callosum in the developmentally disabled population as determined by computerized tomography. Pediatr Neurosci 1985-1986;12:101-3. [PubMed] [CrossRef]

5. Sotiriadis A, Makrydimas G. Neurodevelopment after prenatal diagnosis of isolated agenesis of the corpus callosum: an integrative review. Am J Obstet Gynecol 2012;206:337. e1-5. [PubMed] [CrossRef]

6. Monteagudo A, Timor-Tritsch IE. Prenatal diagnosis of CNS anomalies other than neural tube defects and ventriculomegaly. Wilkins-Haug L, Levine D, Barss VA, editors. Waltham, MÄ: UpToDate Inc. https://www.uptodate.com (Accessed on July 21, 2019.) 
7. Alberman E, Mutton D, Morris JK. Cytological and epidemiological findings in trisomies 13, 18, and 21: England and Wales 2004-2009. Am J Med Genet A 2012;158A:1145-50. [PubMed] [CrossRef]

8. Pati M, Cani C, Bertucci E, Re C, Latella S, D'Amico R, et al. Early visualization and measurement of the pericallosal artery: an indirect sign of corpus callosum development. J Ultrasound Med 2012;31:231-7. [PubMed] [CrossRef]

9. Griffiths PD, Bradburn M, Campbell MJ, Cooper CL, Graham $\mathrm{R}$, Jarvis D, et al.; MERIDIAN collaborative group. Use of MRI in the diagnosis of fetal brain abnormalities in utero (MERIDIAN): a multicentre, prospective cohort study. Lancet 2017; 389(10068):538-46. [PubMed] [CrossRef]

10. International Society of Ultrasound in Obstetrics \& Gynecology Education Committee. Sonographic examination of the fetal central nervous system: guidelines for performing the 'basic examination' and the 'fetal neurosonogram'. Ultrasound Obstet Gynecol 2007;29:109-16. [PubMed] [CrossRef]

11. Timor-Tritsch IE, Monteagudo A. Transvaginal fetal neurosonography: standardization of the planes and sections by anatomic landmarks. Ultrasound Obstet Gynecol 1996;8:427. [PubMed] [CrossRef]

12. Paladini D, Pastore G, Cavallaro A, Massaro M, Nappi C. Agenesis of the fetal corpus callosum: sonographic signs change with advancing gestational age. Ultrasound Obstet Gynecol 2013;42:687-90. [PubMed] [CrossRef]

13. Turkyilmaz G, Sarac Sivrikoz T, Erturk E, Ozcan N, Tatlı B, Karaman B, et al. Utilization of neurosonography for evaluation of the corpus callosum malformations in the era of fetal magnetic resonance imaging. J Obstet Gynaecol Res 2019;45:1472-8. [PubMed] [CrossRef]

14. Kose S, Altunyurt S, Yıldırım N, Keskinoğlu P, Çankaya T, Bora $\mathrm{E}$, et al. Termination of pregnancy for fetal abnormalities: main arguments and a decision-tree model. Prenat Diagn 2015;35: 1128-36. [PubMed] [CrossRef]

15. Santo S, D'Antonio F, Homfray T, Rich P, Pilu G, Bhide A, et al. Counseling in fetal medicine: agenesis of the corpus callosum. Ultrasound Obstet Gynecol 2012;40:513-21. [PubMed] [CrossRef]

16. Dall'Asta A, van Oostrum NHM, Basheer SN, Paramasivam G, Ghi T, Galli L, et al. Etiology and prognosis of severe ventriculomegaly diagnosed at late gestation. Ultraschall Med 2018;39: 675-89. [PubMed] [CrossRef]

17. Karl K, Esser T, Heling KS, Chaoui R. Cavum septi pellucidi (CSP) ratio: a marker for partial agenesis of the fetal corpus callosum. Ultrasound Obstet Gynecol 2017;50:336-41. [PubMed] [CrossRef]

18. Ghi T, Carletti A, Contro E, Cera E, Falco P, Tagliavini G, et al. Prenatal diagnosis and outcome of partial agenesis and hypoplasia of the corpus callosum. Ultrasound Obstet Gynecol 2010;35:35-41. [PubMed] [CrossRef]

19. de Wit MC, Boekhorst F, Mancini GM, Smit LS, Groenenberg IAL, Dudink J, et al. Advanced genomic testing may aid in counseling of isolated agenesis of the corpus callosum on prenatal ultrasound. Prenat Diagn 2017;37:1191-7. [PubMed] [CrossRef]
20. de Wit MC, Srebniak MI, Govaerts LCP, Van Opstal D, Galjaard RJH, Go AT. Additional value of prenatal genomic array testing in fetuses with isolated structural ultrasound abnormalities and a normal karyotype: a systematic review of the literature. Ultrasound Obstet Gynecol 2014;43:139-46. [PubMed] [CrossRef]

21. Shen O, Gelot AB, Moutard ML, Jouannic JM, Sela HY, Garel C. Abnormal shape of the cavum septi pellucidi: an indirect sign of partial agenesis of the corpus callosum. Ultrasound Obstet Gynecol 2015;46:595-9. [PubMed] [CrossRef]

22. Malinger G, Lev D, Lerman-Sagie T. Is fetal magnetic resonance imaging superior to neurosonography for detection of brain anomalies? Ultrasound Obstet Gynecol 2002;20:317-21. [PubMed] [CrossRef]

23. Malinger G, Paladini D, Pilu G, Timor-Tritsch IE. Fetal cerebral magnetic resonance imaging, neurosonography and the brave new world of fetal medicine. Ultrasound Obstet Gynecol 2017;50:679-80. [PubMed] [CrossRef]

24. Cignini P, D'Emidio L, Padula F, Girgenti A, Battistoni S, Vigna R, et al. The role of ultrasonography in the diagnosis of fetal isolated complete agenesis of the corpus callosum: a longterm prospective study. J Matern Fetal Neonatal Med 2010;23: 1504-9. [PubMed] [CrossRef]

25. Pilu G, Sandri F, Perolo A, Pittalis MC, Grisolia G, Cocchi G, et al. Sonography of fetal agenesis of the corpus callosum: a survey of 35 cases. Ultrasound Obstet Gynecol 1993;3:318-29. [PubMed] [CrossRef]

26. Volpe P, Paladini D, Resta M, Stanziano A, Salvatore M, Quarantelli M, et al. Characteristics, associations and outcome of partial agenesis of the corpus callosum in the fetus. Ultrasound Obstet Gynecol 2006;27:509-16. [PubMed] [CrossRef]

27. Malinger G, Ben-Sira L, Lev D, Ben-Aroya Z, Kidron D, LermanSagie T. Fetal brain imaging: a comparison between magnetic resonance imaging and dedicated neurosonography. Ultrasound Obstet Gynecol 2004;23:333-40. [PubMed] [CrossRef]

28. Malinger G, Lev D, Lerman-Sagie T. Is fetal magnetic resonance imaging superior to neurosonography for detection of brain anomalies? Ultrasound Obstet Gynecol 2002;20:31721. [PubMed] [CrossRef]

29. Di Mascio D, Sileo FG, Khalil A, Rizzo G, Persico N, Brunelli R, Giancotti A, Panici PB, Acharya G, D'Antonio F. Role of magnetic resonance imaging in fetuses with mild or moderate ventriculomegaly in the era of fetal neurosonography: systematic review and meta-analysis. Ultrasound Obstet Gynecol 2019;54:164-71. [PubMed] [CrossRef]

30. ENSO working group. Role of prenatal magnetic resonance imaging in fetuses with isolated mild or moderate ventriculomegaly in the era of neurosonography: a multicenter study. Ultrasound Obstet Gynecol 2020 Jan 9. doi: 10.1002/uog. 21974 [PubMed] [CrossRef]

31. Sheiner E, Shoham-Vardi I, Weitzman D, Gohar J, Carmi R. Decisions regarding pregnancy termination among Bedouin couples referred to third level ultrasound clinic. Eur J Obstet Gynecol Reprod Biol 1998;76:141-6. [PubMed] [CrossRef] 